\title{
EFECTO DE LA COBERTURA DE PAJA EN SUELOS HORTÍCOLAS
}

\author{
BONEL, B. A. ${ }^{1}$; FIRPO, I. T. ${ }^{2}$; ROTONDO, R. ${ }^{2}$; \\ FerRatto, J. A. ${ }^{2} \&$ Longo, A. ${ }^{2}$
}

\begin{abstract}
RESUMEN
El objetivo de este trabajo fue evaluar las modificaciones en algunas propiedades de un suelo del Cinturón Hortícola de Rosario luego de tres años de mantenimiento de cobertura con paja. Se compararon parcelas sin cobertura (SC) y con cobertura (CC) de paja dispuestas en un diseño de bloques completos aleatorizados. Los datos se analizaron aplicando la prueba $\mathrm{t}$-Student. El Carbono orgánico y la estabilidad de agregados se modificaron a partir del primer año de aplicación de la cobertura en los $10 \mathrm{~cm}$ superficiales, siendo los valores mayores en CC. En esta situación se comprobó la estratificación del Carbono y el aumento de estabilidad de agregados como consecuencia de un aumento en la resistencia al hinchamiento y dispersión. A pesar que la porosidad total fue mayor en CC, la macro y microporosidad porosidad no fueron significativamente diferentes entre SC y CC, y tampoco se hallaron diferencias significativas en los valores de Conductividad Hidráulica Saturada.

Palabras clave: cobertura, suelos hortícolas, carbono orgánico, estabilidad de agregados, porosidad.
\end{abstract}

\section{SUMMARY}

\section{Straw mulch effect on horticultural soil properties.}

The objective of this study was to evaluate soil properties modifications in Rosario's Horticultural Belt after three years of straw mulch cover. Plots with (CC) and without (SC) straw mulch cover were compared in a completed randomized block design. The results were analized by t-Student test. Organic carbon and aggregate stability were modified from the first year of the cover addittion in the 10 superficial $\mathrm{cm}$, being bigger the values for CC. In this situation it was proved the stratification of Carbon and the increasing of aggregate stability due to a greater swelling and dispersion soil resistant. Although total porosity was bigger in $\mathrm{CC}$, the macro and microporosity wasn't significantly different between $\mathrm{SC}$ and $\mathrm{CC}$, and nor does it were found significantly differences in Hidraulic Conductivity.

Key words: mulch, horticultural soil, organic carbon, aggregate stability, porosity.

1.- Cátedra de Manejo de Tierras. Facultad de Ciencias Agrarias, Universidad Nacional de Rosario. Parque Villarino. C. C. 14. (2125) Zavalla, provincia de Santa Fe. Email: bonel@arnet.com.ar

2.- Cátedra de Sistemas de Producción Hortícola. Facultad de Ciencias Agrarias (UNR).

Manuscrito recibido el 3 de marzo de 2003 y aceptado para su publicación el 15 de noviembre de 2004. 